\title{
Comprehensive Review on Ayurvedic Formulations and Herbal Medicines for Treatment of Rheumatoid Arthritis
}

\author{
Farha Sultana $^{1,2}$, Bhavika Arora ${ }^{1}$, Sandeep Arora ${ }^{1}$, Rakesh K. Sindhu ${ }^{1 *}$ \\ ${ }^{1}$ Chitkara College of Pharmacy, Chitkara University, Punjab, India \\ ${ }^{2}$ Devsthali Vidyapeeth college of Pharmacy, Lalpur, Udham Singh Nagar, Rudrapur, \\ Uttarakhand, India \\ *Email: rakesh.sindhu@chitkara.edu.in
}

DOI: $10.51201 / J U S S T / 21 / 07218$

http://doi.org/10.51201/JUSST/21/07218

\section{Abstract}

Rheumatoid arthritis, an autoimmune inflammatory disorder is characterized by progressive cartilage erosion leading to joint destruction, pain, stiffness and swelling. Although, the etiology of the disease is unknown, but genetic changes due to factors such as environmental agents, immune response towards infectious agents influences rheumatoid arthritis. Earlier NSAID's were the first choice of drugs for the treatment of disease but due to having certain side effects and limitations, herbal therapies which possess higher efficacy and safety are now in demand. There are hundreds of plants which have phytoconstituents that exhibit anti-inflammatory activity. Combination of plants are used to make polyherbal formulations which act synergistically to give anti-arthritic activity. The review is about the botanicals and traditional formulations which have been clinically tested for the treatment against Rheumatoid arthritis.

Keywords: Ayurvedic Formulations, Herbals, Arthritis, Phytoconstituents, NSAIDs.

\subsection{Introduction}

Rheumatoid arthritis (RA) where "artho" means joint and "itis" means inflammation. It is a chronic autoimmune inflammatory disease which on progression results into joint damage, pain, disability and even mortality. The symmetric polyarticular disease predominantly affects the small diarthrodial joints of feet and hands. The articular characteristics involves synovial thickening, erythema, and decreased movement of joints. Rheumatoid arthritis is not an inherited disorder rather people with specific genes are more sensitive towards it. The environmental factors, smoking, etc. triggers and activates that genes and then the immune system responds inappropriately and starts destructing the joint. The etiology of rheumatoid arthritis is still unknown. It involves a complex role of both environmental and genetic factors that triggers it to occur. Zvaifler in 1973 formulated a hypothesis behind the disease which initiates with the formation of immune complex by rheumatoid factors complemented by antibodies and release of variety of mediators such as cytokines, C5a. Inflammatory mediators invade the joint and contribute to the local joint damage. In arthritis there is not only synovial inflammation but also the destruction of articular structures due to invasion of pannus, the aggressive front tissue. There is also presence of reactive oxygen species at the site of inflammation due to increase synovial cavity pressue, vascular changes, decreased capillary density, and increase in metabolism of 
synovial tissue. In diseases like arthritis the immune system's self-tolerance is destroyed and the body attack its own components. Rheumatoid arthritis affects nearly 0.5 to $1 \%$ of adult population in the developed countries. The prevalence of disease is less common in countries like South Africa, Nigeria, Pakistan, China, as compared to people in Western countries. Moreover, the disease is more common in female population than males.

Increase in population of the patients, the research of effective treatment becomes a need. Earlier the treatment involves the use of NSAID's, DMARD's, and glucocorticoids. But they were not found to be save as the long use involves hepatic and certain GIT disorders. Then, herbal and folk medicines becomes an alternative approach for the treatment.[1-3]

Table 1. Risk factors associated with Rheumatoid arthritis.

\section{Factor}

\begin{tabular}{|c|c|}
\hline Age & $\begin{array}{l}\text { Men and women both at the age of } 35-65 \text { are at } \\
\text { higher risk. }\end{array}$ \\
\hline Gender & $\begin{array}{l}\text { Women are at higher risk of disease than men. } \\
\text { Primarily the period just after pregnancy is the } \\
\text { highest risk time for the chances of development of } \\
\text { rheumatoid symptoms. }\end{array}$ \\
\hline Environmental & $\begin{array}{l}\text { Bacterial and viral infections caused by Mycoplasma, } \\
\text { rubella virus triggers symptoms of rheumatoid } \\
\text { arthritis. }\end{array}$ \\
\hline Genetic & $\begin{array}{l}\text { The genes that encode the Human leukocyte antigens } \\
\text { (HLA) are responsible for the autoimmune response } \\
\text { in the disease. Individuals with HLA DRB } 1 \text { alleles } \\
* 0101 * 0401 * 0404 * 0405 \text { are at a higher risk of } \\
\text { disease. }\end{array}$ \\
\hline
\end{tabular}

\section{0 Etiology}

While Rheumatoid arthritis is considered as inflammatory disease without a cause. But it has observed as the disease is a cause of genetic susceptibility by environmental agents, or an immune response to an infectious antigen. Because the process by which genetic or environmental agents because RA is still unknown and that is why disease is called as “idiopathic”. [4]

\subsection{Pathogenesis}

Themost commonly affected synovial joints involved in rheumatoid arthritis aremetacarpophalangeal and proximal interphalangeal joints of hands, wrist, metatarsophalangeal joints of knee, toes, and shoulder The joint is formed by the bones and 
separated by a fluid called synovial fluid and the influx of various inflammatory mediators such as mast cells, T-cells, B-cells, macrophages cause the abnormal inflammation of synovial membrane of a joint which results into synovitis and then rheumatoid arthritis.[5-6]

\subsection{Role of immunity}

The immune system consists of two barriers involved in providing immunity. First, innate immunity which consist of external skin and mucus membrane, phagocytes and natural killer cells. Second, adaptive immunity consists of B-lymphocytes and T-lymphocytes. The overstressed response of adaptive immune system in response of auto-antibodies is responsible for the inflammation in Rheumatoid arthritis. [5]

\section{2 Role of B-lymphocytes}

B-lymphocytes when get activated, differentiate into plasma cells. Plasma cells further produce auto-antibodies in case of Rheumatoid arthritis, known as rheumatoid factor. The auto-antibodies form a complex that causes release of inflammatory mediators like cytokines and influence the tissue damage.[7]

\section{3 Role of T-lymphocytes}

In RA, $\mathrm{T}$ cells are involved in division, release and activation of macrophages and proinflammatory factors like interleukin, TNF- $\alpha$, interferon $\gamma$, which promote the inflammation. Toll like receptors present on macrophages release cytokines, prostaglandins, and matrix metalloproteinase in the synovial fluid, invades cartilage and promotes destruction. Osteoclasts, the main cells of bone destruction are also stimulated by inflammatory mediators released by 
macrophages.

[8].
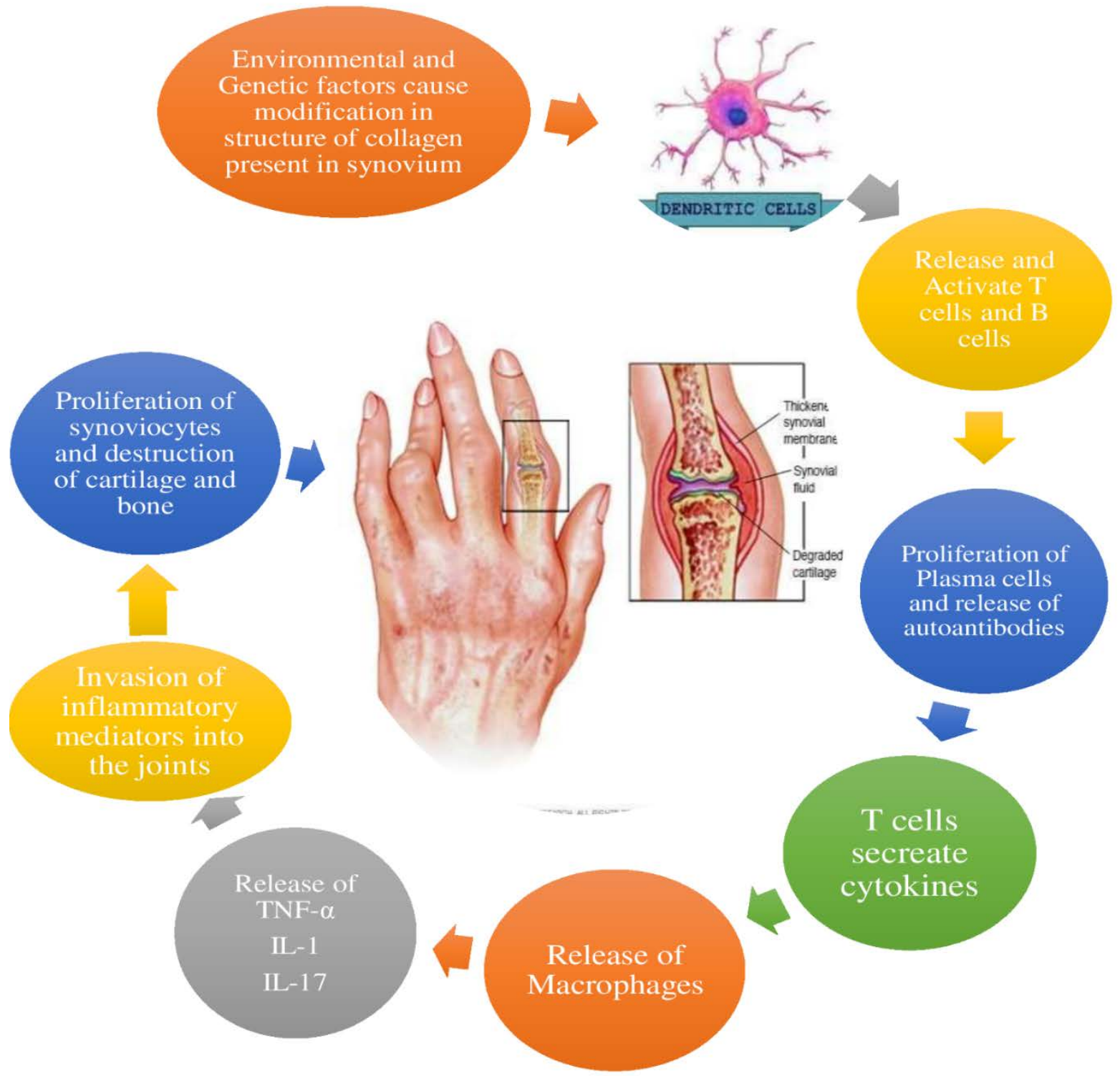

Figure 1: Pathogenesis involved in Rheumatoid Arthritis [6-7]

\subsection{Herbals as anti-inflammatory agents in Rheumatoid arthritis}

From centuries, Medicinal plants contain various biological active compounds for treatment and management of various diseases and their symptoms. Even before synthetic allopathic drug discovery, man completely rely on herbal plants having health benefits for the disease treatment. Medicinal plants in the form of crude material serve as a crucial raw material for the 
development of herbal medicines. India being the richest source of medicinal plants worldwide has maintained the position in the production of bioactive compounds as raw material in formulation of pharmacological therapeutic agents.

Rheumatoid arthritis is one of the diseases for which the patients require alternative herbal therapy along with DMARD's commonly used drugs for the condition. Not in India only, various people in US also prefer botanicals, herbal formulations as an approach to treat their health problems. The American College of Rheumatology also commends the use of herbal medicines in the treatment due to their long-term effects and less adverse effects[9-10].

\subsection{Botanicals in Rheumatoid arthritis}

\section{Achillea millefolium Linn.}

The perennial herb of Asteraceae family is well recognized for the treatment of RA because of its anti-inflammatory properties. The presence of secondary plant metabolites like phenols and isoprenoids contribute to the anti-inflammatory potential of herb. The anti-inflammatory action is due to inhibition of arachidonic acid metabolism. The presence of dicaffeoyquinic acids and flavonoids in the plant extract inhibits human neutrophil esterase and matrix metalloproteinases, which are responsible for inflammation. [11]

\section{Adhatodavasica}

The indigenous herb of Acanthaceae family is given in various forms like decoction, infusion, powder, fresh juice for the treatment of rheumatic inflammation. The plant is rich in alkaloids, tannins, flavonoids, terpenoids and glycoside. The paw edema study on albino rats confirmed the anti-inflammatory potential of the herb.

\section{Aconitum heterophyllum}

The plant belongs to the family of Valeraneaceae is used for treatment of various diseases together with rheumatoid arthritis. The ethanolic extract of the plant contains alkaloids, glycosides, flavonoids, and sterols as the major phytoconstituents. These phytochemicals are responsible for the inhibition of prostaglandins pathway and possess anti-inflammatory potential. The plant has also the potential of inhibiting arachidonic acid metabolism.

\section{Aloe barbadensis}

The herb is also known as Aloe vera belonging to family Liliaceae. The plant is indigenously grown inin many parts of India andEurope. It is rich in anthraquinones, cinnamic acid, anthracene, and anthranilic acid which are responsible for the anti-rheumatic effects. [9]

\section{Actaea racemosaLinn.}

The plant is commonly known as black cohosh, black snakeroot or bugwort, belonging to the family Ranunculaceae. The active constituents of plant are actinia, cimigoside, steroidal terpenes, tannins, isoflavones, formonoetine decrease the inflammation produced due to RA. 


\section{Bacopa monnieri Linn.}

The plant of Scrophulariaceae family was used earlier as brain tonic, cardio tonic, and improve respiratory function. The plant was also determined for its antirheumatic activity when tested on rats paw. It possess anti-inflammatory activity by inhibiting inflammatory mediators production and metabolism. The main components triterpenoids, and bacosides are responsible for inhibiting the production of cytokines and show anti-inflammatory response. [11]

\section{Camellia sinensis}

The herb is oftenly consumed as a beverage because of no adverse effects and known as Green tea. Green tea show its pharmacological action due to polyphenols or catechins present in it. After pre-clinical studies on rat, green tea extract was observed in inhibiting pro-inflammatory mediators production and suppress the serum levels of immunoglobulins produced. In another study called mouse collagen induced arthritis, green tea was determined to be potentially active by reducing inflammatory mediators like TNF- $\alpha$, IFN- $\gamma$, and COX-2 in the joints of mice. [12]

\section{Cassia fistula Linn.}

The herb belonging to the family of Caesalpiniaceae, is pharmacologically active in treatment of various skin and inflammatory diseases. The bark of the tree show significant anti-inflammatory effect. The herb is rich in flavonoids and bio-flavonoids which can be used in the management of inflammatory ailments including Rheumatoid arthritis. [13]

\section{Curcuma longa}

It is belonging to theZingiberaceae family, commonly known as turmeric. From centuries, the herb is being used for its anti-inflammatory properties. The major constituent of the plant is curcumin. The herb shows decrease in arthritis induced paw edema in rats. Curcumin, inhibits arachidonic acid pathway by inhibiting the significant enzymes. It also other inflammatory mediators production such as leukotrienes, $\mathrm{PGE}_{2}$ and macrophages secretions hyaluronidase, collagenase, and elastase. [12]

\section{Calotropis procera Linn.}

The plant is the species of dogbane family Apocynaceae, grows in regions of North Africa, Tropical Africa, Western and Southern Asia. The plant's latex part shows potent antiinflammatory activity. It inhibits the inflammatory cells invasion and edema formation. It also improves locomotor activity in arthritic patients. The plant at dose of $180 \mathrm{mg} / \mathrm{kg}$ of methanol extract gives AIA against paw edemainduced by carrageenan in rat model. [9]

\section{Daphne pontica Linn.}

The plant belongs to the Thymelaeaceae family and is active against cancer from $2^{\text {nd }}$ century. The plant contain bioactive compounds like daphnodorins (flavonoids). It has been used against inflammatory diseases like rheumatoid arthritis as it inhibits the production of $\mathrm{PGE}_{2}$ and IL-1 $\beta$. [14] 


\section{Embilica officinalis}

The commonly used amla tree grows in the tropical and parts ofsubtropical India, China and Indonesia. This plant of Euphorbiaceae has been used in treatment and management of arthritic pain as it inhibits the synthesis of inflammatory mediators such as leukotrienes, platelet activating factor, and thromboxane. [15]

\section{Ficus bengalensis Linn.}

The plant is commonly known as Banyan tree grows in India's subcontinent regions, belongs to the family Moraceae. The bioactive compounds present are $\alpha-\mathrm{L}$ rhamnoside, leucocynidin, glucoside, $\beta$ sitosterol $\alpha$-D and pentatriacontan-5-one,. The presence of phytoconstituents like , tannins, flavonoids, sapnonins, steroids contribute to the anti-rheumatic activity of banyan tree. [9]

\section{Garcinia mangostana Linn.}

The fruit belongs to the family of Guttiferae, has been widely used as traditional medicine for treatment of rheumatoid arthritis and other skin infections. The fruit hulls of mangosteen is rich in xanthones, $\alpha$-and $\gamma$-mangostins. Xanthones inhibits nitric oxide synthase and mangostins ae involved in decreasing $\mathrm{PGE}_{2}$ production. Both these actions contribute to the anti-inflammatory potential of the plant. [16]

\section{Hemidumus indicus Linn.}

This plant belongs to the family of Asclepiadaceae, mostly found in South Asia. The bioactive constituents present in it are coumarin, tannic acid, essential oil, and triterpenoid saponin. The plant is used in treatment of RA, chronic ulcers and many skin diseases. The oral treatment with ethanolic extract of plant reduces paw volume, and paw thickness in just 8 days. [9]

\section{Justicia gendarussa Linn.}

The evergreen plant belongs to Acanthaceae family, grows in moist areas. The main chemical constituents are carbohydrates,alkaloids, flavonoids, tannins, andsugar. Apigenin, a flavonoid is used as an anti-arthritic agent. The ethanolic extract of the plant also show similar anti-arthretic activity as aspirin on collagen induced arthritic rat models.

\section{Lantana camara Linn.}

The verbenaceae family plant, is widely used in treatment of tumours and cancer. The plant also shows anti-inflammatory, anti-malarial, antibacterial, analgesic and anti-hemorrhoidal activities.

The tea prepared from leaves of the plant shows potential against influenza, fever, and stomachache. [17]

\section{Mangifera indica Linn.}

The plant is acknowledged as mango, belonging to the family of Anacardiaceae. Mango is widely used for variety of diseases. The ethanolic extract of the plant shows anti-inflamatory 
activity. The bioactive compound flavonoids present in it are responsible for inhibiting prostaglandin synthesis and treating rheumatic disease. [18]

\section{Piper nigrum Linn.}

Black pepper, belongs to the Piperaceae family and is cultivated in South region of India. Pepper is rich in bioactive compounds such as alkaloids, volatile oil, resins, piperine, piperidine, and starch. Piperine from black pepper shows anti-inflammatory potential inpaw arthritisinduced by carrageenan when administered orally for eight days at the dose of 20 and $100 \mathrm{mg} / \mathrm{kg} / \mathrm{day}$. [9]

\section{Ricinus communis}

The plant of Euphorbiaceae family, grows in Tropical and Sub-tropical regions of the world. The pre-clinical studies on albino rats determined the anti-inflammatory and anti-oxidant activities of plant. The pharmacological potential is due to the presence of bioactive compounds like alkaloids, flavonoids, and tannins. [19]

21. Sesbania sesban Linn.

Sesbania plant belongs to leguminosae family, and has a lot pharmacological potential. The presence of various bioactive compounds such as terpenoids, steroidal saponins, tannins and flavonoids are reported for the anti-rheumatic activity. The anti-inflammatory potential was proved in the rat paw edema induced by carrageenan, where the herb has the inhibitory action against inflammation. [20]

\section{Terminalia paniculata}

The commonly called kindal tree belongs to the Combretaceae family. The tall kindal tree is native to Southwest India. The bioactive constituents includes alkaloids, flavonoids, triterpenes, saponins, and tannins. The water extract of herb shown anti-inflammatory action at a dose of 200 $\mathrm{mg} / \mathrm{kg}$. [21]

\section{Uncaria tomentosa}

The Woody vine plant is native to tropical jungle of Southern and Central America. It is also known as Cat's claw because of its thorny appearance. It contains alkaloids, tannins as potentially active compounds. The phytoconstituents present are ajmalicine, campesterol, epicatechin, chlorgenic acid, palmitoleic acid, oleanic acid, rutin, sitosterols, speciophylline, stigmasterol. In preclinical studies on rat model, the herb shows inhibitory action against carrageenan induced paw edema. [12]

\section{Withaniasomnifera}

The herb is acknowledged as ashwagandha or Indian ginseng. Ashwagandha is the traditionally active plant. The plant grown in dry sub-tropical regions like Punjab,Rajasthan, Gujarat Haryana, and Madhya Pradesh. Ashwagandha is rich in alkaloids pseudo-withanine, tropine,like withanine, pseudo-tropin, somnine,somniferine, and two acyl glucosides sitoindoside-7, and sitoindoside-8. The plant shows various activities such asanti-tumour, anti-inflammatory, anti- 
depressant, and against anxiety. Upon, oral administration of root powder of plant, it gives antiarthretic activity. [22]

\section{Zingiber officinale}

Ginger is the other common name of the herbal plant. Ginger contains volatile oil, starch, fat, fibre, hydrocarbons, mono and sesquiterpenes, and inorganic material. It shows various activities including, anti-inflammatory, antiemetic, carminative antioxidant, antifungal and anti-microbial. Zingiberene, and sesquiterpene lactones in the ginger extract are responsible for the antiinflammatory activity. [12]

There is wide variety of herbal plants used to treat chronic joint inflammation and arthritis. These herbal plants can be used as both internally or externally in the treatment. Here are some more examples of herbal plants used in treatment of arthritis and its inflammation.

Table 2: Botanicals used in treatment of RA [23-24]

\begin{tabular}{|c|c|c|c|c|}
\hline S.NO. & Herbal Plant & $\begin{array}{l}\text { Common } \\
\text { Name }\end{array}$ & Family & Phytoconstituents \\
\hline 1. & Ammanniabaccifera & Aginbuti & Lythraceae & $\begin{array}{l}\text { Hentriacontine, dotriacontanol, } \\
\text { betulinic acid, lupeol, ellagic } \\
\text { acid, quercitin, lawsone, } \beta \text { - } \\
\text { sitosterol }\end{array}$ \\
\hline 2. & Andographispaniculata & Bhuin Neem & Acanthaceae & $\begin{array}{l}\text { Alkaloids, steroids, flavonoids, } \\
\text { triterpenoids, quinones, protein, } \\
\text { sugars, gum }\end{array}$ \\
\hline 3. & Phyllanthus niruri & Chankapeidra & Phyllanthaceae & $\begin{array}{l}\text { Brevifolin, butyrolactone, } \\
\text { dibenzyl butyrolactone, } \\
\text { corilagin, cymene }\end{array}$ \\
\hline 4. & Cedrus deodara & Deodar cedar & Pinaceae & $\begin{array}{l}\text { Himachalene, himachalol, } \\
\text { allohimachalol, himadarol, } \\
\text { centdarol, ethyl laurate, ethyl } \\
\text { stearate, beta-sitosterol, } \\
\text { shikimic acid, methyl coniferin }\end{array}$ \\
\hline 5. & Tectona grandis & Teak & Lamiaceae & $\begin{array}{l}\text { Astectoquinone, ,betulinic } \\
\text { aldehyde tectol, betulinic acid, } \\
\text { acetovanillone, 5- } \\
\text { hydroxylapachol, squalene, } \\
\text { syringaresinol, zhebeiresinol }\end{array}$ \\
\hline 6. & Boswellia serrata & Shallaki & Burseraceae & Boswellic acid, p-cymene- \\
\hline
\end{tabular}




\begin{tabular}{|c|c|c|c|c|}
\hline & & & & $\begin{array}{l}\text { limonene, terpinolene, bornyl } \\
\text { acetate, valencene, sabinol, } \beta \text { - } \\
\text { eudesemene }\end{array}$ \\
\hline 7. & Terminalia chebula & Myrobalan & Combretaceae & $\begin{array}{l}\text { Arjunglucoside, trans-cinnamic } \\
\text { acid, triethyl ester of chebulic } \\
\text { acid, arjunic acid, arjungenin, } \\
\text { daucosterol }\end{array}$ \\
\hline 8. & Curcuma Amanda & Amoda & Zingiberaceae & $\begin{array}{l}\text { Curcumin, demethoxy } \\
\text { curcumin, bis-demethoxy } \\
\text { curcumin }\end{array}$ \\
\hline 9. & Dalbergia sissoo & Sisu & Fabaceae & $\begin{array}{l}\text { Isoflavone, mesinisited, } \\
\text { isocaviumin, tetorigeni, } \\
\text { dalbergin, tanniuns, } \\
\text { dalberginone, dalberichromene }\end{array}$ \\
\hline 10. & Sidacordifolia & Bazramuli & Malvaceae & $\begin{array}{l}\text { Alkaloids, phytosterols, } \\
\text { flavonoids, glycosides, } \\
\text { saponins, fixed oils }\end{array}$ \\
\hline 11. & Ocimumbasilicum L. & Ban tulsi & Lamiaceae & $\begin{array}{l}\text { Terpenoids, alkaloids, } \\
\text { flavonoids, tannins, saponin, } \\
\text { glycosides and ascorbic acid }\end{array}$ \\
\hline 12. & Thespesia populnea & Portia & Malvaceae & $\begin{array}{l}\text { Alkaloids, vcarbohydrates, } \\
\text { proteins phenols, terpenes } \\
\text { flavonoids, gums, saponins, }\end{array}$ \\
\hline 13. & Lycopodium clavatum & Club moss & Lycopodiaceae & Alkaloids, steroids, flavonoids \\
\hline 14 & $\begin{array}{l}\text { Phyllanthus } \\
\text { polyphyllus }\end{array}$ & Amla & Euphorbiaceae & $\begin{array}{l}\text { Lignins, triterpenoids, } \\
\text { flavonoids, tannins }\end{array}$ \\
\hline 15. & $\begin{array}{l}\text { Tripterygium } \\
\text { wildfordii }\end{array}$ & Hook F & Celastraceae & $\begin{array}{l}\text { Sesquiterpenoids, diterpenes, } \\
\text { triterpenoids, flavonoids, } \\
\text { lignans }\end{array}$ \\
\hline
\end{tabular}




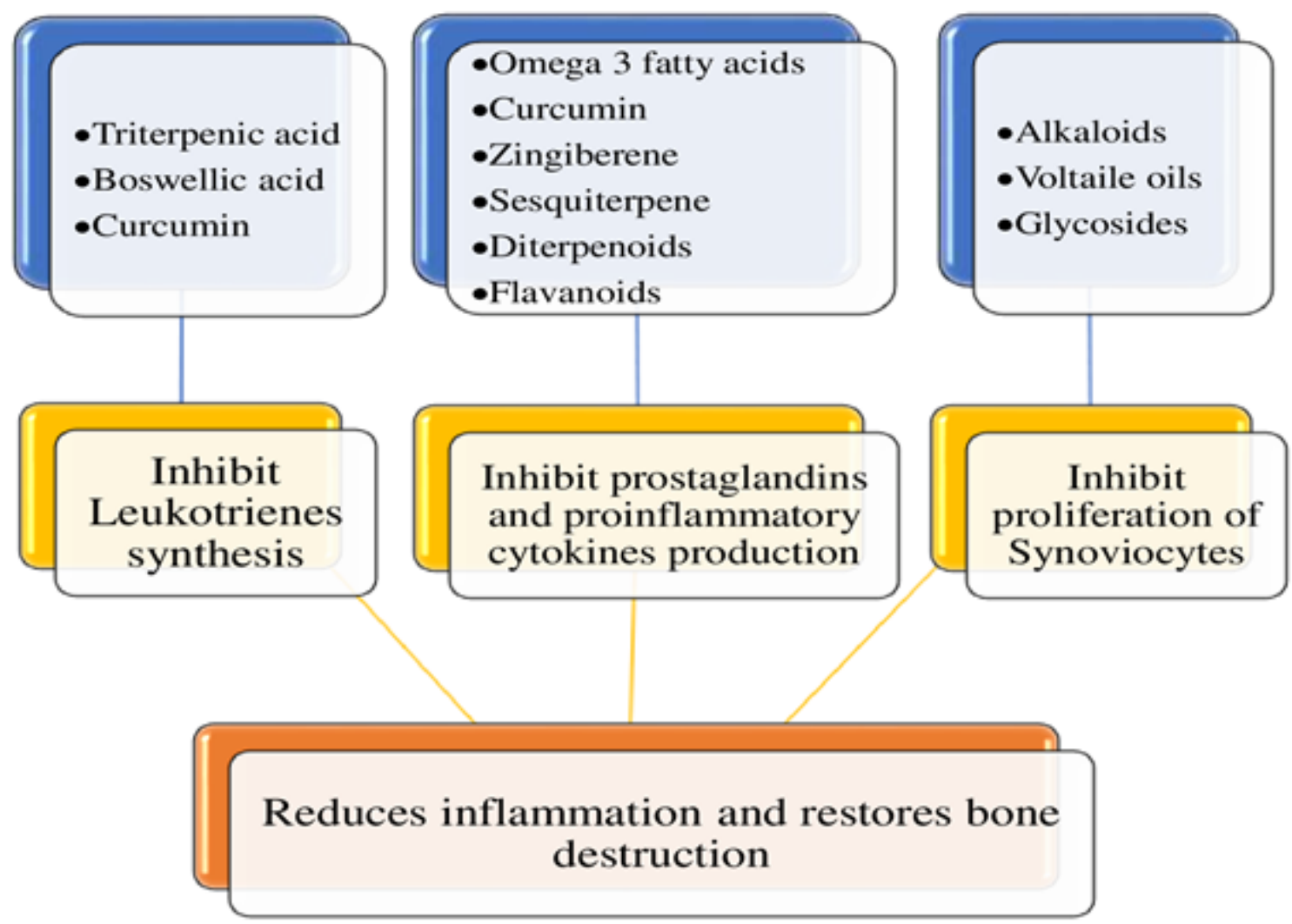

Figure 2: Some phytoconstituents possessing anti-rheumatic activity

\subsection{Traditional medicinal formulations in arthritis}

In today's world medicine is created on traditional system of medicine. Indigenous medicine systems, like Ayurveda, Chinese, Unani and Siddha systems are used to prevent and manage the disease conditions. Herbal medicines are the oldest and beneficial form of healthcare for mankind. Earlier, rheumatoid arthritis has been treated by NSAID's but due to their high risk of blood clotting, formulations from herbal plant came into development and now Herbal therapy is the most extensively used therapy for the treatment RA.[25]

\subsection{Ayurvedic formulations for Rheumatoid arthritis}

It isoriginatesfrom two words "Ayur" i.e. life, and "Veda" means science. It was came into existence for over 5,000 years ago. Ayurvedic formulations promote the healthy wellbeing of patients by focusing on their mind, body and spirit because the purpose of this system of medicine is to maintain the equilibrium between different forces of body which are responsible for any disease condition. So, the medicines are selected and prepared on the basis of patient's disease condition, severity of disease and body constitution in order to maintain balance the internal body forces. The formulations are not simple, but contain many herbs that are prepared and administered by traditional principles of Ayurveda science. Some Ayurvedic formulations used in treatment of arthritis.[26] 
1. In India, this classic ayurvedic formulation has been used from years to treat rheumatoid arthritis. It is a combination of equal amount of fine powders of dried pericarp of plants including Terminaliachebula, Terminalia belerica, Phyllanthus embilica,Commiphoramukul (oleo gum resins), sulphur containing Gandhaksuddha, and VatariTaila a castor oil.

The formulation was tested on male Wistar albino rats. The drug was administered in different groups of animals at different doses. It was observed that the group of animals administered with the dose of $270 \mathrm{mg} / \mathrm{kg}$ and $540 \mathrm{mg} / \mathrm{kg}$ shows maximum inhibition of joint swelling.

Guggulu, one of the main constituent of the formulation contain phytochemical guggulsteroneswhich are responsible for suppressing DNA binding of NF-kappa induced by TNF-, and IL-1 and exhibit anti-inflammatory activity. The formulation not only reduce the inflammation but also has the potential of relieving arthritis symptoms. VatariGuggulu was also found to be free from toxicity and safe to use for the treatment. [27]

\section{Triphala}

It is most commonly used Ayurvedic herbal formulation, consisting of fruits of three trees i.e.Embilicaofficinalis (Indian goose berry), Terminalia belerica(Belleric myrobalan), Terminalia chebula(Chebulic myrobalan) in equal proportions.

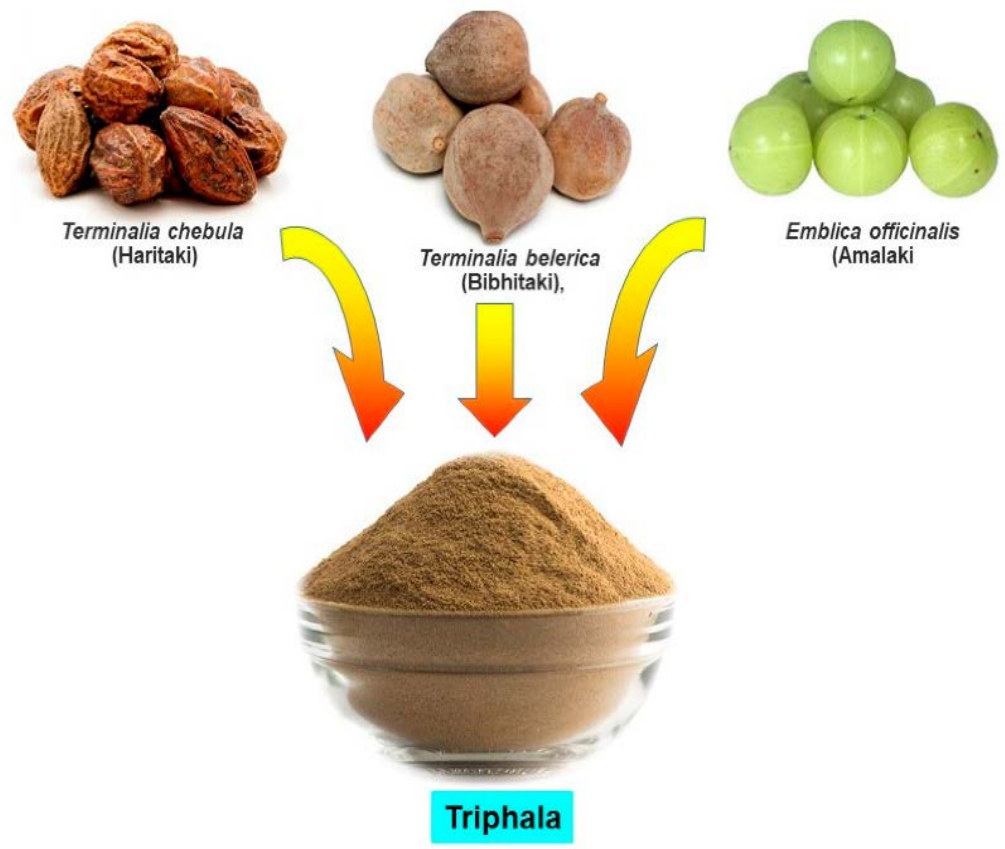

The polyherbal Ayurvedic formulation exhibit various health benefits such as anticancer, antimutagenic, anti-inflammatory and antioxidant. As per study results Triphala causes immunosuppression during inflammation and therefore used to treat inflammatory and autoimmune diseases. Triphala is rich in Vitamin C, ellagic acid, chebulinic acid, bellericanin, $\beta$ sitosterol, gallic acid, and flavonoids alkaloids, polyphenols, terpenoids and glycosides which are responsible for anti-inflammatory activity. The activity was analysed on arthritis induced Swiss albino mice. Triphala inhibits the production of mediators responsible for 
inflammation.Overproduction of prostaglandins results into pain, fever, swelling, and cartilage damage in arthritis. Triphala has shown inhibitory action on COX-2 by blocking NF- $\square$ B mediated inflammatory pathway. There is decrease in serum levels of inflammatory mediators when compared with arthritic control animals. [28-29]

\section{RA-1}

This herbal formulation was prepared from plant extracts of Withaniasomnifera, Boswellia serrate,Zingiber officinalis, and Curcuma longa. The formulation was under trials for several weeks and then found to be an excellent drug for use. [30]

\section{IRA-01}

This is prepared from plant extracts of Boswellia serrate, trigonellafoenum-graecum, Linumusitatissimum, Camellia sinensis, Curcuma longa, Tribulus terrestris and Piper nigrum.After, randomized double blind trials, open-label phase trial it was observed that IRA-01 was a slow acting disease modifying antirheumatic drug with little or no side effects and improve the disease condition of arthritis patients.

\section{Articulin-F}

It is the indigenous ayurvedic formulation, prepared from herbal extracts of Withaniasomnifera, Boswellia serrata, Curcuma longa and Zinc. The clinical efficacy of the drug was evaluated in randomized, double-blind, placebo controlled, and cross over studies in patients of rheumatoid arthritis. All the formulation ingredients were reported to be effective against rheumatoid arthritis. The herb Withanisomnifera, also acknowledged as Ashwagandha found to be very effective ingredient in the formulation due to having anti-inflammatory activity and decrease in production of inflammatory mediators. Curcumin from curcuma longa and $\beta$-boswellic acid from Boswellia serrata also exhibit anti-inflammatory activity and give relief from the pain in arthritis. Deficiency of zinc in rheumatoid arthritis is also filled by its supplementation. It is believed that the combination of all effective herbs lead to the synergistic action. Therefore, after clinical trials of the drug it is found to be effective, safe for the treatment of arthritis. [31]

6. Sudard

It is a polyherbal Ayurvedic formulation prepared from 11 plant extracts.

\begin{tabular}{|l|l|}
\hline Plant name & $\begin{array}{l}\text { Quantity taken for each } \\
\text { tablet }\end{array}$ \\
\hline Guggulu & $100 \mathrm{mg}$ \\
\hline Rasna & $50 \mathrm{mg}$ \\
\hline GandhaPrasarini & $50 \mathrm{mg}$ \\
\hline Nirgundi & $50 \mathrm{mg}$ \\
\hline Ginger & $50 \mathrm{mg}$ \\
\hline Erandamula & $50 \mathrm{mg}$ \\
\hline Chandra sura & $30 \mathrm{mg}$ \\
\hline
\end{tabular}




\begin{tabular}{|l|l|}
\hline Suranjan & $30 \mathrm{mg}$ \\
\hline Dwipantrawacha & $30 \mathrm{mg}$ \\
\hline Kupilu & $10 \mathrm{mg}$ \\
\hline Shilajatu & $50 \mathrm{mg}$ \\
\hline
\end{tabular}

All these ingredients have potential against anti-inflammatory activity and used in treatment of inflammation involved in rheumatoid arthritis, osteoarthritis, chronic back ache. Sudard under preclinical trials, inhibited the rat paw edema induced by formalin. The formulation also showed analgesic activity under eddy's hot plate and Acetic acid induced writhing test and therefore also used to treat pain during arthritis. The release of histamine, prostaglandins and other mediators responsible for pain, and inflammation are inhibited by Sudard effectively. [32]

\section{Rumalya Forte}

It is the polyherbal Ayurvedic dosage form, used for rheumatoid arthritis for years now. The formulation ingredients showed anti-inflammatory, anti-arthretic, immunomodulatory, muscle relaxant and analgesic activity. The table below shows the plant extracts present in the formulation along with their mechanism of action. The synergistic activity of the formulation was analysed on arthritis induced rats. [33]

\section{Herbal Plant $\quad$ Mechanism of action}

\begin{tabular}{l|l|}
\hline Boswellia serrate & Inhibits leukotriene synthesis \\
\hline Alpinia galangal & $\begin{array}{l}\text { Inhibits release of pro-inflammatory cytokines such as } \\
\text { IL-1- } \beta \text {, TNF- } \alpha \text {, COX-2, NF-kappa- } \beta\end{array}$ \\
\hline Commiphorawightii & Inhibits release and regulation of TNF- $\alpha$ and IL-1- $\beta$ \\
\hline Glycyrrhiza glabra & Possess strong inflammatory activity \\
\hline $\begin{array}{l}\text { Tinospora cordifolia } \\
\text { Tribulus terrestris }\end{array}$ & Inhibits production of IL-1- $\beta$ and TNF- $\alpha$ \\
\hline & Inhibits activity of COX-2 enzyme \\
\hline
\end{tabular}

\subsection{Traditional Chinese formulations in arthritis}

Thearthritis can be treated with traditional Chinese medicines has become very popular in china and other Asian countries. About $75 \%$ of the Chinese population prefer these formulations for arthritis, fatigue, musculoskeletal pain and other lifestyle disorders. Now, at preset number of traditional Chinese formulations are being discovered and use which show clinical potency against rheumatoid arthritis. According to Chinese system of medicine $\mathrm{Bi}$ syndrome (Rheumatoid arthritis) is caused by wind, cold, and dampness. The formulation ingredients of Chinese medicines act synergistically to give anti-inflammatory and antiarthritic effect. [34] 


\section{Celastrus}

This Chinese formulation is being used from decades for treatment of arthritis and other inflammatory disorders. Celastrus contains triterpenes such as celastrol, celasdin C, flavonoids such as epiafzelechin, and sesquiterpenes such as orbiculin F. As per preclinical trials done on rats, the formulation shows anti-inflammatory activity by altering the ratio of anti and proinflammatory cytokines. Celastrus was also observed for the decreasing mediators of bone damage like granulocyte macrophage colony stimulating factor.Another study of ethyl acetate extract of celastrus in rat model shows reduction of arthritis symptoms and synovial inflammation. The mechanism of action behind is the increase in cell death rate of synoviocytes and lymphocytes, and induce the function of CD4, CD25, and other T cells. [35]

2. Huo-luo-xiao-ling-dan

It is a polyherbal Chinese formulation containing 11 herbs shown in the table. The herbal formulation was tested on arthritis induced lewis rats. The formulation show positive results in reducing clinical and histological symptoms of arthritis. There is decrease in production of inflammatory mediators such as cytokines- IL-1 $\beta$, IL-6, and IL-7, matrix metalloproteinase-9, chemokines, macrophages, and other bone damaging mediators. The pathways including metabolism, immune response, inflammation, apoptosis are also altered which significantly

Results into anti-arthritic activity of the drug.

\begin{tabular}{ll|l} 
Botanical name & Chinese name \\
\hline Boswellia carterii & Ruxiang \\
\hline Notopterygiumincisum & Qianghuo \\
\hline Angelica sinensis & Danguii \\
\hline Paeonia lactiflora & Chisao \\
\hline Glycyrrhiza uralensis & Gancao \\
\hline Corydalis yanhusuo & Yanhusuo \\
\hline Salvia miltiorrhiza & Danshen \\
\hline Ligusticum chuanxiong & Chuanxiong \\
\hline Gentian macrophylla & Qinjiao \\
\hline Cinnamomum cassia & Guizhi \\
\hline Angelica pubescens & Duhuo \\
\hline
\end{tabular}

Here are some Chinese proprietary medicines for Rheumatoid arthritis. [34] 


\begin{tabular}{|l|l|l|}
\hline $\begin{array}{l}\text { Name of Chinese } \\
\text { medicine }\end{array}$ & $\begin{array}{l}\text { Type of } \\
\text { formulation }\end{array}$ & Formulation ingredients \\
\hline BizhongXiao & Decoction & $\begin{array}{l}\text { BaihuaSheshecao, Danshen, Luoshiteng, } \\
\text { Gusuibu, Yiiren, }\end{array}$ \\
\hline HanShiBi & Pill & $\begin{array}{l}\text { Fuzi, Chuanwu, Huangqi, Guizhi, Mahuang, } \\
\text { Baizhu, Baishao, Mugua, Xixin }\end{array}$ \\
\hline KunXian & Capsule & $\begin{array}{l}\text { Kunming shanhaitang, Yinyanghuo, } \\
\text { Gouqizi, Tusizi } \\
\text { Dangshen, Baishao, Baizhu, Danshen, } \\
\text { Chuanxiong, Sanqi, Maqianzi }\end{array}$ \\
\hline YishenJuanBi & Capsule & $\begin{array}{l}\text { Shudi, Danggui, Yinyanghuo, Luxiancao, } \\
\text { Quanxie, Jiangcan, Wugong, Fengfang, } \\
\text { Dilong, Wushaoshe }\end{array}$ \\
\hline
\end{tabular}

\subsection{Traditional Siddha formulations for arthritis}

Tamilian Siddha system of medicine, is widely used in the region of South India. This system of medicine is known for is rich heritage and history. The term Siddha refers to achievements of "Siddhars", the saintly persons in medicine. The 18 Siddhars are involved in the development of this system. According to siddha system of medicine, the patient is first treated with botanicals and then with metal and animal products. Many plants, metals, minerals are researched for their anti-inflammatory activity, to develop formulations for the treatment of rheumatoid arthritis. [36]

Table 3: The table shows the Siddha plants used internally or externally for the treatment of rheumatoid arthritis. [37]

\section{Botanical name Tamil Family Phytoconstituents Name}

\begin{tabular}{l|l|l|l|}
\hline $\begin{array}{l}\text { Acalypha } \\
\text { fruticosaForsk. }\end{array}$ & Chinni & Euphorbiaceae & $\begin{array}{l}\text { Alkaloids, phenols, saponins, flavonoids, } \\
\text { and amino acids }\end{array}$ \\
\hline $\begin{array}{l}\text { Adenantherapavonia } \\
\text { Linn. }\end{array}$ & Anai-kunri & Leguminaceae & $\begin{array}{l}\text { Robinetin, chalcone, butin, } \\
\text { flavanolampelopsin, stigmasterol } \\
\text { glucosides, oleanic acid, echinocystic acid, } \\
\text { sapogenins }\end{array}$ \\
\hline $\begin{array}{l}\text { Boerhaaviadiffusa } \\
\text { Linn. }\end{array}$ & Mukka-ratai & Nyctaginaceae & $\begin{array}{l}\text { Phenolic glycosides, terpenoids, organic } \\
\text { acids, boeravinones A-J, isoflavone, } \\
\text { flavonol, glycosides, xanthone, lignin }\end{array}$ \\
\hline Citrullus & Attruthumatti & Cucurbitaceae & Diterpenoids, saponin, sterols, flavonoids, \\
\hline
\end{tabular}




\begin{tabular}{l|l|l|l}
\hline colocynthisSchard. & & carbohydrate, and alkaloids \\
\hline $\begin{array}{l}\text { Crinum asiaticum } \\
\text { Linn. }\end{array}$ & Vishamungil & Amaryllideae & $\begin{array}{l}\text { Alkaloids, flavonoids, tannins, phenols, } \\
\text { cardiac glycosides, triterpenes, steroids, } \\
\text { and saponins }\end{array}$ \\
\hline Jatropacurcas Linn. & Katt-amanukku & Euphorbiaceae & $\begin{array}{l}\text { Phenols, tannins, free amino acids, phytic } \\
\text { acid }\end{array}$ \\
\hline Mollugocerviana Ser. & Parpatakam & Ficoidaceae & $\begin{array}{l}\text { Carbohydrates, proteins, thiols, flavonoids, } \\
\text { phenols, terpenoids,glycosides, tannins, } \\
\text { alkaloids, steroids, gums and mucilages }\end{array}$ \\
\hline $\begin{array}{l}\text { Sesbania grandiflora } \\
\text { Pers. }\end{array}$ & Sev-agathi & Leguminaceae & $\begin{array}{l}\text { Alkaloids, flavonoids, glycosides, } \\
\text { triterpenoids, saponins }\end{array}$ \\
\hline Ziziphus jujuba Linn. & Elandai & Rhamnaceae & $\begin{array}{l}\text { Flavonoid C-glycoside, triterpene acids, } \\
\text { unsaturated fatty acids }\end{array}$ \\
\hline
\end{tabular}

\section{Conclusion}

Rheumatoidarthritis is an inflammatory disorder which has now become the most common cause of disability in people all over the world. The treatment of the disease involves the use of NSAID's and DMARD's, but due to their side effects and more awareness in patients, they are driving their attention towards other therapies such as herbal therapy. Since ancient time, plants have played an important role in healthcare of society. Traditional medicines play an excellent role in research and development of new herbal formulations. Plants have proven to be the great anti-inflammatory agents. Due to increase in public interest, there is a need to research for more herbal medicines and development of suitable effective formulations which could be beneficial for rheumatoid arthritis and other inflammatory disorders.

\section{0 Acknowledgement}

The authors are grateful to Dr. Madhu Chitkara, Vice Chancellor, Chitkara University, Rajpura, Patiala, India and Dr.Ashok Chitkara, Chancellor, Chitkara University, Rajpura, Patiala, India, for support and institutional facilities.

\section{References}

1. Firestein GS. Evolving concepts of rheumatoid arthritis. Nature. 2003;423(6937):356-61. 
2. Hughes SD, Ketheesan N, Haleagrahara N. The therapeutic potential of plant flavonoids on rheumatoid arthritis. Critical reviews in food science and nutrition. 2017;57(17):3601-13.

3. Ramteke R. Management of Rheumatoid Arthritis through Ayurveda. J Tradi Med Clin Natur. 2016;5(189):2.

4. Australian Institute of Health and Welfare. Arthritis and musculoskeletal condition in Australia 2005 - with a focus on osteoarthritis, rheumatoid arthritis and osteoporosis. Canberra: Australian Institute of Health and Welfare; 2005.

5. Marieb E, Hoehn K. Human anatomy and physiology, 7th ed. San Francisco: Pearson Benjamin Cummings; 2007.

6. McInnes IB, Schett G. The pathogenesis of rheumatoid arthritis. New England Journal of Medicine. 2011;365(23):2205-19.

7. Smolen J, Aletaha D, Koeller M, et al. New therapies for treatment of rheumatoid arthritis. Lancet 2007;370:1861-74.

8. Smolen J, Steiner G. Therapeutic strategies for rheumatoid arthritis. Nature Reviews Drug Discovery 2003;2:473-88.

9. Kaur A, Nain P, Nain J. Herbal plants used in treatment of rheumatoid arthritis: a review. Int J Pharm Pharm Sci. 2012;4(Suppl 4):44-57.

10. Soeken KL, Miller SA, Ernst E. Herbal medicines for the treatment of rheumatoid arthritis: a systematic review. Rheumatology. 2003;42(5):652-9.

11. Kumar S, Bajwa BS, Kuldeep S, Kalia AN. Anti-inflammatory activity of herbal plants: a review. Int J Adv Pharm Biol Chem. 20132(2):272-81.

12. Ahmed S, Anuntiyo J, Malemud CJ, Haqqi TM. Biological basis for the use of botanicals in osteoarthritis and rheumatoid arthritis: a review. Evidence-Based Complementary and Alternative Medicine. 2005 Sep;2.

13. Ilavarasan R, Malika M, Venkataraman S. Anti-inflammatory and antioxidant activities of Cassia fistula Linn bark extracts. African journal of traditional, complementary and alternative medicines. 2005;2(1):70-85.

14. Kupeli E, Tosun A, Yesilada E. Assessment of anti-inflammatory and antinociceptive activities of Daphne ponticaL.(Thymelaeaceae). Journal of ethnopharmacology. 2007;113(2):332-7.

15. Asmawi MZ, Kankaanranta H, Moilanen E, Vapaatalo H. Anti-inflammatory activities of Emblica officinalis Gaertn leaf extracts. Journal of Pharmacy and Pharmacology. 1993 Jun;45(6):581-4

16. Chen LG, Yang LL, Wang CC. Anti-inflammatory activity of mangostins from Garcinia mangostana. Food and Chemical Toxicology. 2008;46(2):688-93. 
17. Gidwani BK, Bhargava S, Rao SP, Majoomdar A, Pawar DP, Alaspure RN. Analgesic, antiinflammatory and anti-hemorrhoidal activity of aqueous extract of Lantana camara Linn. Research Journal of Pharmacy and Technology. 2009;2(2):378-81.

18. Mascolo N, Autore G, Capasso F, Menghini A, Fasulo MP. Biological screening of Italian medicinal plants for anti-inflammatory activity. Phytotherapy research. 1987;1(1):28 -31.

19. Ilavarasan R, Mallika M, Venkataraman S. Anti-inflammatory and free radical scavenging activity of Ricinus communis root extract. Journal of ethnopharmacology. 2006;103(3):478-80.

20. Dande PR, Talekar VS, Chakraborthy GS. Evaluation of crude saponins extract from leaves of Sesbania sesban (L.) Merr. for topical anti-inflammatory activity. International Journal of Research in Pharmaceutical Sciences. 2010;1(3):296-9.

21. Talwar S, Nandakumar K, Nayak PG, Bansal P, Mudgal J, Mor V, Rao CM, Lobo R. Antiinflammatory activity of Terminalia paniculata bark extract against acute and chronic inflammation in rats. Journal of Ethnopharmacology. 201;134(2):323-8.

22. Mirjalili MH, Moyano E, Bonfill M, Cusido RM, Palazón J. Steroidal lactones from Withaniasomnifera, an ancient plant for novel medicine. Molecules. 2009;14(7):2373-93.

23. Singh H, Krishna G, Baske PK. Plants used in the treatment of joint diseases (rheumatism, arthritis, gout and lumbago) in Mayurbhanj district of Odisha, India. Report and opinion. 2010;2(9):22-6.

24. Kumar SS, Bhosle D, Janghel A, Deo S, Raut P, Verma C, Agrawal M, Amit N, Sharma M, Giri T, Tripathi DK. Indian Medicinal Plants Used for Treatment of Rheumatoid Arthritis. Research Journal of Pharmacy and Technology. 2015;8(5):597-610.

25. Rathore B, Mahdi AA, Paul BN, Saxena PN, Das SK. Indian herbal medicines: Possible potent therapeutic agents for rheumatoid arthritis. Journal of clinical biochemistry and nutrition. 2007;41(1):12.

26. Basnyat S, Kolasinski SL. Ayurvedic medicine for rheumatoid arthritis. Current rheumatology reports. 2014;16(8):435.

27. Patel MG, Pundarikakshudu K. Anti-arthritic activity of a classical Ayurvedic formulation VatariGuggulu in rats. Journal of traditional and complementary medicine. 2016;6(4):389-94.

28. Sabina EP, Rasool MK, Mathew L. In vivo and in vitro immunomodulatory effects of Indian ayurvedic herbal formulation triphala on experimental induced inflammation. Pharmacologyonline. 2009;2:840-9.

29. Kalaiselvan S, Rasool MK. The anti-inflammatory effect of triphala in arthritic-induced rats. Pharmaceutical biology. 2015;53(1):51-60.

30. Chopra A, Saluja M, Tillu G. Ayurveda-modern medicine interface: A critical appraisal of studies of Ayurvedic medicines to treat osteoarthritis and rheumatoid arthritis. Journal of Ayurveda and integrative medicine. 2010;1(3):190. 
31. Kulkarni RR, Patki PS, Jog VP, Patwardban B. Efficacy of an Ayurvedic formulation in rheumatoid arthritis: a double-blind, placebo-controlled, cross-over study. Indian Journal of Pharmacology. 1992;24(2):98.

32. Asad M, Prasad K, Thomas L, Kamath JV. Evaluation of anti-arthritic and anti-inflammatory activity of Sudard, a poly herbal formulation. Iranian Journal of Pharmacology and Therapeutics. 2007;6(1):71-5.

33. KR S, Cheriyan BV, Parvathavarthini S, Bhaarati GM, Venugopal V. Effect of polyherbal formulation Rumalaya forte on adjuvant induced arthritis in rats. Indian Drugs. 2012;49(10):10.

34. Pan HD, Xiao Y, Wang WY, Ren RT, Leung EL, Liu L. Traditional Chinese Medicine as a Treatment for Rheumatoid Arthritis: From Empirical Practice to Evidence-Based Therapy. Engineering. 2019 Aug 22.

35. Venkatesha SH, Astry B, Nanjundaiah SM, Kim HR, Rajaiah R, Yang Y, Tong L, Yu H, Berman BM, Moudgil KD. Control of autoimmune arthritis by herbal extracts and their bioactive components. asian journal of pharmaceutical sciences. 2016;11(2):301-7.

36. Joseph B, Jini D, Ajisha SU. Phytochemical characterization of herbal drug formulation for arthritis. Res J Phytochem. 2012;6(2):54-60.

37. Wilson E, Rajamanickam GV, Vyas N, Agarwal A, Dubey GP. Herbs used in siddha medicine for arthritis-a review. IND. J of traditional knowledge 2007 6(4):678-86. 